\title{
Modern Aspects of Home Economics Education and Slovenia
}

MARTINA ERJAVšEK ${ }^{1}$

$\approx$ Home economics operates in the academic, curriculum and social realms, as well as in everyday life. Due to its multidisciplinarity, it includes and interconnects the contents of different disciplines (e.g., healthy lifestyle, nutrition, dietetics, textiles, home, family, consumption, personal and family economics, design and technology), which are considered in terms of meeting the needs of the individual, family, and society. Home economics education and literacy play an important role in acquiring knowledge and skills that help raise the quality of life of the individual, family, and society. With the development of society, the needs of both the individual and the family are changing; therefore, changes are also needed in home economics education, which is reflected in the updating of the subject curricula. The goals and contents in the curriculum must reflect and meet the needs of the current society and take into account the cultural dependence and social determinism of the home economics field. To a certain extent, the current curriculum of the subject home economics in Slovene elementary schools already includes some content areas that have been recognised as important for meeting the needs of society. These relate to healthy lifestyle, nutrition, health, textiles, consumption, economics, family, environment and sustainable development. Given the perceived needs of society, the use of household appliances, home contents, and first aid should be additionally included in home economics education in Slovenia, and students should be encouraged to develop social and communication skills. It is also necessary to consider the appropriate placement of the subject in the curriculum, as it is necessary to implement home economics education in the entire elementary school education. Doing so will enable the acquisition of knowledge and skills needed in society and, therefore, the appropriate level of home economics literacy of the individual.

Keywords: home economics education, teaching home economics literacy, quality of life, needs of society, Slovenia

1 Faculty of Education, University of Ljubljana, Slovenia; martina.erjavsek@pef.uni-lj.si. 


\section{Sodobni vidiki gospodinjskega izobraževanja v Sloveniji}

Martina ERJAvšEK

$\approx$ Gospodinjstvo deluje na akademskem, šolskem in na družbenem področju ter v vsakdanjem življenju. Zaradi svoje multidisciplinarnosti vključuje in med seboj povezuje vsebine različnih disciplin (npr. zdrav življenjski slog, prehrana, dietetika, tekstil, dom, družina, potrošnja, osebna in družinska ekonomika ter dizajn in tehnologija), ki se obravnavajo $\mathrm{z}$ vidika zadovoljevanja potreb posameznika, družine in družbe. Gospodinjsko izobraževanje in opismenjevanje imata pomembno vlogo pri usvajanju znanj in veščin, ki pripomorejo k dvigu kakovosti življenja posameznika, družin in družbe. Z razvojem družbe se spreminjajo potrebe posameznika in družin, zato so potrebne tudi spremembe na področju gospodinjskega izobraževanja, ki se kažejo v aktualizaciji učnih načrtov predmeta. Cilji in vsebine v učnem načrtu morajo odražati in zadovoljevati potrebe trenutne družbe ter upoštevati kulturno odvisnost in socialno determiniranost področja gospodinjstvo. $\mathrm{V}$ trenutni učni načrt predmeta gospodinjstvo v slovenski osnovni šoli so v določenem obsegu že vključena nekatera vsebinska področja, ki so bila prepoznana kot pomembna za zadovoljevanje potreb družbe. Ta se nanašajo na zdrav življenjski slog, prehrano, zdravje, tekstil, potrošnjo, ekonomiko, okolje in na trajnostni razvoj. Glede na zaznane potrebe družbe pa bi bilo treba v gospodinjsko izobraževanje v Sloveniji dodatno vključiti tudi vsebine o domu, uporabi gospodinjskih aparatov in prvi pomoči ter učence spodbujati k razvijanju socialnih in komunikacijskih veščin. Treba je razmisliti tudi o ustrezni umestitvi predmeta v predmetnik, saj se kaže potreba po izvajanju gospodinjskega izobraževanja v celotnem osnovnošolskem izobraževanju. Le takšno gospodinjsko izobraževanje bi omogočalo usvajanje znanj in veščin, potrebnih v družbi, in s tem ustrezno stopnjo gospodinjske pismenosti posameznika.

Ključne besede: gospodinjsko izobraževanje, gospodinjsko opismenjevanje, kakovost življenja, potrebe družbe, Slovenija 


\section{Introduction}

Rapid social, political and economic changes impact the structure of society, which evolves with time. Changes in society considerably impact educational systems, which need to be reformed to be adaptable and compatible with the challenges and problems of modern times (Becirović \& Akbarov, 2015). Education systems are currently responding to societal changes related to the Covid-19 pandemic, which has affected many aspects of everyday and social life. It has aggravated problems in health care, finance, consumption, family life and home, nutrition, and social inequalities (Neubauer et al., 2021; Rains et al., 2021; Scarborough et al., 2021). These areas are connected to the contents included in home economics education (IFHE, 2008). This fact demonstrates that home economics education and home economics literacy have an important role in maintaining and developing the quality of life in the social conditions of a crisis.

The present article aims to describe the home economics discipline, the areas of its activities, and the importance of home economics education and literacy. The needs of society for home economics education and literacy, as well as the challenges and problems of this discipline, are well-founded in Slovenia and throughout the world. The position of the subject of home economics in Slovene elementary school education and its integration into the syllabus are presented. The content areas included in the Slovene curriculum of home economics subject and changes suggested for updating its contents are identified. Guidelines for the actualisation of home economics education in Slovenia are given. The purpose of justifying the importance of home economics for society and the suggested guidelines is to encourage the Slovene society, science, and professions to discuss and research how to reform the existing home economics education. When preparing guidelines to actualise home economics education, it is necessary to consider the needs of society and the social and cultural determinism of the home economics discipline. Changes must meet people's needs to have high-quality active lives on the personal, family and social levels. The present article presents a scientific and professional justification of the importance of including home economics in the education system and developing home economics literacy for an individual and society.

A literature search for articles that deal with home economics, home economics education, and home economics literacy was performed. The databases DiKUL, Google Scholar, and PeFprints were searched. Many different search terms were used for literature review (e.g., home economics, home economics education, home economics literacy, home economics and the needs of society, etc.). Furthermore, the references of all retrieved articles were manually 
searched for relevant cross-references. Articles in the English and Slovenian languages were accepted. All retrieved articles were then reviewed. Only articles that were relevant to the purpose of the research were used.

\section{Theoretical Framework}

\section{Home economics and home economics literacy}

In 2008, the International Federation for Home Economics (IFHE), in its basic IFHE Position Statement, defined the home economics discipline as the area which includes research and professional areas of various disciplines that deal with the lives of individuals, families, and communities in the perspective of reaching optimal and sustainable existence. Hira (2013) showed the operation of the home economics discipline from the point of view that home and family are the key building blocks of society, significant in a person's development of norms, values, and beliefs, reflected in their behaviour. In this way, the discipline acts to benefit a person, family, and society (Brown, 1980). Home economics deals with the quality of life in a family, sustainable living and the rational use of available resources (IFHE, 2008). Magee et al. (2010) discuss home economics as a discourse between the financial aspects of consumption and activities in a person's household, influenced by the cultural setting and changes inside their home and family. Home economics is a basic and essential building block of society and economy, for which the main goal is to meet a person's needs. Sproles and Sproles (200o) emphasise the importance of home economics as a multidisciplinary domain, as the contemporary problems and daily challenges have more than one aspect to consider; they require an individual to have varied knowledge and skills to solve them successfully. With its multidisciplinarity, home economics thus connects the contents of various disciplines and deals with them through an interdisciplinary and transdisciplinary approach. The content (disciplinary bases) from which studies of home economics draw is dependent upon the context but might include food, nutrition and health; textiles and clothing; shelter and housing; consumerism and consumer science; household management; design and technology; food science and hospitality; human development and family studies; education and community services, and much more (IFHE, 2008). Benn (2008) points out the diverse nature of home economics can be its shortcoming, since many of its research areas are dealt with by other disciplines that are better defined and established. Thus she emphasises that a relevant definition of the field and a critical solving of problems from individual, family, and community perspectives are necessary, as otherwise home economics can easily be lost among other 
disciplines. Particular areas included in the home economics discipline are often stressed, but not home economics as an umbrella discipline (Hira, 2013); therefore, some authors (Magee et al., 2010) consider the division of home economics to particular areas to be meaningless.

Home economics operates in four different areas of practice, described by IFHE in its 2008 Position Statement. The first is the academic area that provides education for new researchers who will carry out new research and develop new knowledge. This interconnects and works together with the area of everyday living. It researches the lives of individuals, families, and communities and, based on research findings, identifies and emphasises problems and challenges met by these categories in society. The second is the area of everyday living that enables the needs of individuals and families to be met. It includes an individual's skills and capacity to perform various tasks in everyday life. It focuses on happy and high-quality living, a positive living environment, and the well-being of individuals and families. The third curriculum area enables discovering and developing pupils' capabilities to reach their full potential for meaningful and successful activities in life. It is connected to the area of everyday living, as the purpose of home economics education is in acquiring relevant knowledge and skills and their use in actual life situations. The fourth segment is the societal area, which provides the development of various strategies for the well-being of individuals, families, and society. Wahlen et al. (2009) point out that the areas of functioning of home economics complement each other, thus strengthening each other while still acting separately and independently. Hodelin (2008) asserts that the concept should include the fifth segment of the discipline, namely personal awareness, which enables the home economics discipline, its importance, and well-being to be promoted. Its key promoters should be home economics teachers.

The IFHE Position Statement (2008) describes the key dimensions of home economics that represent basic professional guidelines that must be included in every home economics education. The first dimension represents basic needs and practical everyday solutions for various life situations of an individual and family for their well-being and functioning in society. The second dimension represents a multidisciplinary inclusion of knowledge and skills of various disciplines included in home economics. The third key dimension presents critical and reforming measures or actions to increase the quality of life for individuals and families.

Based on areas and key dimensions of home economics, Pendergast (2015) has conceived a model of home economics literacy (i.e., the Home Economics Literacy Model (HELM)). HELM presents a touchpoint between areas 
and key dimensions. Despite the design of the HELM model, there is still no evidence of a single definition for home economics literacy in the world (Pendergast, 2013). Pendergast (2015) states that the home economics discipline researches and endeavours to establish the concept of home economics literacy. IFHE (2015) points out that home economics literacy is a multidisciplinary expression of numerous literacies, including those of the nutrition, health, financial, consumer, and environmental realms. Gale Smith (2013) underscores that literacy is knowledge and the ability to decide and transfer knowledge into everyday living. Similar opinions are held by Sproles and Sproles (2000) as well as Hira (2015), who state that home economics literacy includes not only knowledge and skills, but also the understanding of values, relations, beliefs, habits, experiences, and cultural environment. Kieren et al. (1984) and Stage and Vincenti (1997) state that the main goal of any literacy is to shape a person's behaviour, which is also valid for home economics literacy.

\section{Home economics education}

Home economics education and literacy teaching are of key importance in acquiring the knowledge and skills necessary for quality everyday functioning and living (Dixon, 2017; Lind et al., 2009; Roldan, 2017; Tamm \& Palojoki, 2012). Home economics education enables personal and professional development to individuals and the development of basic life skills that children cannot learn in their home environment, as some studies show (Slater, 2013; Turkki, 2005). According to similar conclusions by Alharbi and Renwick (2017), individuals should acquire unique lifelong skills indispensable for functioning at home and in their careers. Renold (2008) emphasises the purpose of home economics education and literacy teaching, which is to empower individuals and families for their well-being, adopt life-long learning attitudes, and enable future generations to manage global social challenges. Home economics education enables pupils not only to acquire knowledge but also to use and transfer it to theoretical and practical situations (Pendergast et al., 2013). Its importance is also in the development of appropriate attitudes towards various home economics contents (Volāne, 2014). Caraher and McCloat (2016) point out that it can act as a platform for solving everyday situations and meeting a person's needs. Education focuses on pupils acquiring home economics knowledge and skills and developing their personal and social skills (Lind et al., 2009). Dixon (2017) considers that it gives pupils the ability to perceive the world around them critically. At the same time, she stresses that pupils acquire knowledge and skills not studied in other subjects during home economics classes. Home economics education and literacy teaching are important for developing pupils' 
skills related to economics, consumption, textiles, nutrition, healthy lifestyles, and health promotion (Lichtenstein \& Ludwig, 2010; Pendergast, 2008).

Home economics is crucial for transmitting the basic nutrition knowledge and skills obtained with practice. Doing so can result in reduced rates of obesity and chronic non-infectious illnesses (Slater \& Hinds, 2014). Pupils obtain knowledge of health promotion and sustainability problems, which contributes to their empowerment in terms of a healthy lifestyle and responsible, sustainable living. They also obtain knowledge and skills referring to financial literacy. They acquire social skills that enable their successful communication and high-quality cooperation, group work, acceptance of opinions and coordination with others, which leads to improved problem-solving. Home economics contributes to pupils' general level of knowledge and their positive self-perception, independence and self-confidence, and enable a higher quality of life (Dixon, 2017; Urek, 2018). They encourage creativity and logical thinking in pupils (Lind et al., 2009). It is evident that the home economics discipline truly functions in an individual's everyday life and makes it possible that the needs of the individual and the family are met. At the same time, this area is connected to the school domain: through home economics education and the literacy process, pupils acquire home economics knowledge and skills and use them in their everyday living. Dixon (2017) shows the importance of home economics education and literacy not only for an individual and family but for society; the importance of home economics education for the well-being and functioning of an individual in society is stressed. Kostanjevec et al. (2017) and Pendergast et al. (2013) state that society acquires independent and autonomous individuals who take care of their health and connect nutrition literacy with sustainable behaviour. A society with a healthier population has reduced healthcare expenditure. Erjavšek et al. (2019) state that appropriate home economics literacy facilitates persons' inclusion and acceptance in society. People with acquired home economics knowledge and skills contribute to society by fulfilling norms regarding hygiene and self-care. They also draw attention to the importance of critically assessing information to which modern society is exposed through media and advertising. Therefore, they stress the importance of informed consumer choices, which are more accessible to a person literate in home economics. In their opinion, home economics education and literacy teaching add to social well-being through financial literacy.

Home economics education differs around the globe. Differences appear in the way of teaching and organisation of work in the subject and even its name. Variety is also present in the contents of subject curricula (Lindblom et al., 2013; Olafsdottir et al., 2017). Pendergast (2012) emphasises that, at the global level, home economics education is based on uniform theoretical and philosophical 
premises. The premises are published in the fundamental document, IFHE Position Statement (2008), which presents the basic content areas of the home economics discipline. These refer to food, nutrition, healthy lifestyle, dietetics, textiles and clothing, home, consumption, personal and family economics, the person's and family's progress, and design and technology. In its 2016 resolution, IFHE gave additional guidelines for home economics, focusing on developing strategies to promote happiness as an indicator of a person's health and well-being (IFHE, 2016). Gale Smith (2015) mentions that home economics education includes cooking, financial literacy, practical life skills, understanding nutrition systems and the impact of multinationals on nutrition, and environmental and sustainability education. In Harari's (2020) belief, modern education should be based on teaching critical thinking, communication, cooperativeness and creativity. This is also true for home economics education and literacy teaching, since these should prompt pupils to develop $21^{\text {st }}$-century skills, including communication, group work and problem-solving (Collins et al., 2008).

In many countries, education systems are engaged in changing and updating home economics curricula (Dixon, 2017; Lind et al., 2009; Ma \& Pendergast, 2011; Pace et al., 2015; Pridāne, 2017; Tuomisto et al., 2017). Tamm and Palojoki (2012) point out that the actualisation of curricula focuses primarily on meeting the needs of modern society, from both content and didactic-methodical aspects. Moreover, Mølstad (2015) states that curriculum can be understood to reflect the current society. Some authors (Lind et al., 2009; Olafsdottir et al., 2017; Tamm \& Palojoki, 2012;) present concrete cases for updating curricula of home economics or content areas and contents that should be included in curricula, according to their research. Updated curricula should emphasise knowledge and skills that enable children and adolescents to carry out everyday activities at home and to adopt decisions leading to responsible behaviour (Tamm \& Palojoki, 2012). Olafsdottir et al. (2017) emphasise how important it is to include contents that enable health promotion in home economics education. Lind et al. (2009) point out the need of Estonian society to include the contents of financial and nutrition literacy, as well as home furnishing and maintenance, into home economics education. It should also include contents on the maintenance of clothes and basic sewing; however, in their research, these contents were perceived as less important for the successful independent functioning of an individual in everyday living.

\section{Role of home economics education in solving social problems}

Many problems in the areas included in the above-mentioned multidisciplinary concept of home economics are evident and observed in society. 
The areas of this concept referring to the identified problems are emphasised for their importance a) nutrition, b) health, c) finance, d) environment, e) consumption, f) textiles, and g) home and family. Problems in various areas are intertwined and not unequivocal. However, in solving problems in society, home economics education holds an important role. Some contents included in home economics education are identical to areas in which problems in society are perceived. Acquiring knowledge and skills in the areas of nutrition, health, finance, environment, consumption, textiles and home and family enables individuals to become adequately literate in home economics. For example, Gale Smith (2013) alerts readers to the opportunity of the home economics discipline to 'profit' from the consequences of social problems that are reflected in various areas in the discipline and highlight them in the frame of subject curricula and home economics education.

\section{The area of nutrition}

A decrease in the nutrition knowledge and skills in various population groups, which leads to improper eating habits, is observed in society (Werner et al., 2020). A lack of time, improper nutrition knowledge and poor food preparation skills limit healthy nutrition. This is evident in increased consumption of prepared dishes, the consumption of meals in regular and fast-food restaurants, and increased consumption of snacks as a substitute for main meals. Inadequate nutrition knowledge and food preparation skills lead to the consumption of meals with high fat, salt, and sugar contents, which leads to unhealthy eating habits, increased body mass, and obesity (Gale Smith, 2015; Lang \& Caraher, 2001). Therefore many health problems appear that are a consequence of unhealthy eating habits. Lai-Yeung (2011) considers the development and acquisition of proper nutrition skills and knowledge necessary for the long-term improvement of health and social well-being.

Moreover, Woodruff and Kirby (2013) emphasise that children and adolescents learning food preparation skills are an important health-promoting strategy. Nutrition contents are included in the home economics education and literacy process. Thus, home economics education includes nutrition education, enabling pupils to acquire nutrition knowledge and skills and appropriate nutrition literacy. Vidgen and Gallegos (2014) define nutrition literacy as a combination of knowledge, competences or skills and behaviours needed for planning, providing, selecting, preparing and consuming food to meet a person's nutritional needs. However, Pendergast et al. (2011) explain nutrition literacy as a person's ability to obtain, understand, and correctly interpret nutrition information that they use to impact the maintenance of their health positively. 
Appropriate nutrition literacy and nutrition skills of the entire population may contribute to public health and well-being (Pendergast \& Dewhurst, 2012).

\section{The area of health}

The World Health Organization (WHO) defines health literacy as the whole of cognitive and social skills that determine a person's motivation to access information, understand the obtained information and its critical use in ways that promote and maintain good health (Nutbeam, 1998). Home economics literacy also includes the area of health. Home economics education includes some health content referring to personal health, personal hygiene, sleeping behaviour, and a healthy lifestyle, emphasising healthy eating habits. Home economics literacy thus includes some segments of health literacy. Overweight and obesity are among the most serious public health challenges of the $21^{\text {st }}$ century (Lobstein \& Jackson-Leach, 2016). WHO (2021) data show that the spread of obesity between 1975 and 2016 almost tripled globally. In 2016, more than 340 million children and adolescents, aged from 5 to 19 years, were obese or overweight. A higher rate of obesity is evident among groups with lower social-economic status, which can be the consequence of improper lifestyle and environment in which they live.

Consequently, adequate formal nutrition education and informal education in the form of nutrition workshops and courses are important (WHO, 2014). Data from 2016 for Slovenia show that every second adult is eating predominantly unhealthily, while two thirds of adults face risk factors of unhealthy lifestyle, which are the cause of premature morbidity and mortality. Unhealthy eating seems to be particularly typical of males, young adults, less-educated and more socially and economically vulnerable people, to whom more attention will have to be given. The latter select predominantly lower quality food and have particularly unhealthy eating habits. Due to economic reasons or low awareness, they find it more difficult to follow healthy eating recommendations (Gregorič \& Fajdiga Turk, 2018). A healthy lifestyle, which represents one of the indicators of quality life, is also important for people's health. A healthy lifestyle combines healthy behaviours, such as healthy eating habits, sufficient body activity, non-smoking, not taking risks in drinking alcohol, sufficient sleep, and less frequent use of electronic devices. While some people choose to stay healthy through their conscious choices, many carelessly behave unhealthily. For this reason, government policies and programmes for proactive health and wellness must be crafted and implemented (Mominova \& Ibragimova, 2021). 


\section{The area of finance}

The need for citizens to be financially literate is growing in importance, as consumers are tasked with making ever more complex financial decisions in the marketplace (Lusardi \& Mitchell, 2014). The PISA 2012 Assessment and Analytical Framework (OECD, 2013) defines financial literacy as knowledge and understanding of financial concepts and risks, and the skills, motivation, and confidence to apply such knowledge and understanding in order to make effective decisions across a range of financial contexts to improve the financial well-being of individuals and society. Numerous studies (Gale Smith 2013, 2015; OECD, 2009; PISA, 2021; Renold, 2008) indicate the problems of financial illiteracy that lead people to adopt inappropriate financial decisions. This has negative consequences for an individual and society as a whole. Financial literacy is recognised worldwide as a basic life skill. Data from a study carried out in 2012 show that in the area of financial literacy, the achievements of Slovene pupils are below the average in the OECD (OECD, 2014). The highest scores were achieved by pupils in Shanghai, China, followed by above-average scorers in OECD countries (i.e., adolescents aged 15 from Belgium, Estonia, Australia, New Zealand, Czech Republic, and Poland). In addition to Slovenia, low achievement in financial literacy was seen in Russia, France, Spain, Croatia, Israel, Slovakia, Italy, and Columbia (OECD, 2014). Financial education is an important element of economic and financial stability and development (PISA, 2021); it is included in the home economics subject, and it is important that pupils encounter various financial contents and develop financial literacy through home economics education.

\section{The area of the environment}

Humanity is facing various environmental problems, such as climate changes, pollution, loss of biodiversity, and the destruction of living space. Environmental literacy is important in order for people to be able to identify and prevent environmental problems and adopt sustainable behaviours (Casalo \& Escario, 2016). Many studies focus on measuring environmental literacy (i.e., the measuring of environment-related knowledge, attitudes, and behaviours) (Mifsud, 2012). In reference to environmental knowledge, various levels of knowledge are discernible. For instance, on the one hand, researchers in the Netherlands report weak knowledge (Maknun et al., 2016), while, on the other, some studies demonstrate good environmental knowledge of pupils and students in Madagascar, for example (Kaplowitz \& Levine, 2005; Korhenen \& Lappalainen, 2004).

An environmentally literate person should have appropriate environmental knowledge and attitude, environment-friendly behaviour and care for 
environmental problems (Tuncer et al., 2009). Saribas et al. (2014) have established that environmental literacy is the key component of environmental education, with its goal of developing the appropriate level of such literacy in individuals (Casalo \& Escario, 2016).

In home economics education, pupils acquire some environmental contents, referring to environmental pollution and proper waste handling. Pupils develop positive attitudes to the environment; in this way, environmental literacy is included in the concept of home economics literacy. Erjavšek et al. (2021) state that in their home economics lessons, Slovene teachers most often include sustainability topics, referring to nutrition and living space, and less often to finance and textiles. Addressing sustainable topics within the home economics curriculum appears to be necessary for society (IFHE, 2008).

\section{The area of consumption}

Consumption has become an important part of everyday life in modern society, which has prompted the need for consumer education and literate consumers. Consumer education aims to introduce knowledge and skills so that people act as informed, rational, and cautious consumers. Proper education reduces the risks of unwise consumer choices (Benn, 2004; Goldsmith \& Piscopo, 2014; McGregor, 2016; Renold, 2008). Home economics education thus includes consumer education, as some consumer contents are part of the home economics subject. These contents refer to consumer rights and obligations, purchase forms, planning of purchases, advertising, production and consumption of products and services. Pupils develop critical and responsible attitudes to consumption.

\section{The area of textiles}

The textile and clothing industry represents one of the biggest industrial sectors in the world. Global demand for textile products is increasing together with the growth of population and economic development, and with this also its negative impact on the environment, as the textile industry is a major environmental polluter (Allwood et al., 2006). Morgan and Birtwistle (2009) point out the problem of fast fashion that offers consumers trendy low-cost clothes, leading to their impulsive purchase decisions (Joy et al., 2012). In the home economics subject, pupils acquire knowledge and skills referring to textiles. Contents are connected to consumption with the emphasis on responsible purchasing textile products. 


\section{The area of home and family}

Changes in society are tightly connected with the way of life in households and families. A lack of basic, practical life skills related to home and family is evident (Gale Smith, 2015; Renold, 2008). In society, there is an increasing number of divorces, and the proportion of the ageing population is growing, accompanied by related problems of their care and financial vulnerability (Hira, 2015). Home economics education includes content on home and family. Pupils learn about the concept of family and understand that members have different roles within it. Moreover, the contents refer to mutual relations and domestic tasks and prevent accidents at home. Pupils thus acquire knowledge and skills referring to this area.

\section{Problems and challenges of home economics education}

Salter and Hinds (2014) draw attention to the gap between the current position of home economics education, mostly marginalised in many education systems and the evident problems at various levels of society. Moreover, Pendergast (2001) states that the position of the home economics discipline and thus the home economics subject in education systems and society has been uncertain for a long time. Home economics is often marked as a women's domain (Davis, 2008), which is supported by the fact that it is primarily women who have been active in the history and development of home economics. The functioning of the discipline has focused on home and private settings without interfering in the public sphere. The stigmatisation of this area has been influenced by the factor of unpaid work of women in their households (Pendergast, 2001; Pendergast et al., 2011). The subject has been intended to prepare women for their role in society: as a wife, mother and housekeeper (Caraher \& McCloat, 2016).

Pendergast et al. (2011) state that society fails to recognise the potential and benefits of home economics. The current global trend shows that home economics holds no prioritised position in school syllabi and gains no special attention, which does not mean, however, that the subject contents lack importance or relevance (Pendergast, 2012). Home economics is often perceived and treated as a side subject with the status of an elective and not a mandatory subject (Pendergast, 2001). In many countries, it has been removed from the timetable or fragmented to separate content areas (IFHE, 2008). Current social demands focus on reading, mathematical and natural science literacy; therefore, pressure on pupils is much stronger in these subjects (Pendergast, 2012). In Slovenia, the pupils' knowledge of these subjects is verified at the national and international levels (e.g., the Programme for International Student Assessment 
(PISA), Progress and International Reading Literacy Study (PIRLS), Trends and International Mathematics and Science Study (TIMSS)). In Slovenia, home economics is the only mandatory elementary school subject that is not verified at the national assessment of knowledge (RIC, 2021).

Nevertheless, the attitude that various stakeholders in the education process have towards home economics in Slovene elementary school is positive. Teachers perceive the contents of the subject as important and useful for pupils' further life and their future career orientation and development. In the light of their complexity, subject contents are perceived as less demanding by teachers than other subjects (Erjavšek \& Lovšin Kozina, 2015). Lah (2015) came to a similar conclusion: teachers perceive home economics as an important educational subject. Parents are aware that it is important to teach their children home economics literacy in view of their learning and adopting essential life knowledge and skills (Matos, 2016). They consider it important for children to acquire knowledge of various specialised areas, but they attribute a higher value to the crucial subjects for secondary school enrolment (Urek, 2018). Home economics students share a positive attitude towards the subject, as they agree that it is important to transfer basic home economics knowledge and skills to the young and that home economics contents are important for the quality of life of an individual in society. However, they consider home economics to be less demanding than other subjects (Štirn, 2016). Foreign research shows similar results; Turkki (2005) concluded that students in Finland classify home economics among the less demanding subjects in terms of content. Canadian students have a positive attitude to home economics education, asserting that it must be included in primary school education (Slater \& Hinds, 2014). Nanayakkara et al. (2018) emphasise that Australian adolescents and their parents have high expectations regarding home economics. Höijer et al. (2011) have established that Swedish pupils also have a positive attitude to the subject. They perceive skills acquired at home economics classes to be useful for further life, without, however, considering them to be necessary to meet their needs for a quality life. From that perspective, parents should be advised to encourage their children to use home economics knowledge and skills in home settings. Moreover, other studies (Olafsdottir et al., 2017; Street, 2006) refer to findings that the home economics subject is popular with pupils, since they have an opportunity to participate in both practical and theoretical activities. Despite that, Slater (2013) states that home economics, in comparison to maths, is perceived as less important.

Numerous studies emphasise the problems of inadequate competence of home economics teachers (Dewhurst \& Pendergast, 2008; Håkansson, 2015; 
Lindblom et al., 2013). Between $20 \%$ and $23 \%$ of Swedish teachers teach home economics contents without the corresponding formal education (Lindblom et al., 2013); according to some data (Håkansson, 2015), the percentage of such teachers in Sweden is even higher: about 70\%. Lah (2015) estimates that there are about $37 \%$ of such teachers in Slovenia, which matches a similar conclusion (36\%) by Kostanjevec et al. (2018).

Problems related to gender inequality are still discernible in literature (Ma \& Pendergast, 2011; Pendergast et al., 2011; Street, 2006). In some private male schools, the belief persists that boys with wealthy parents need no nutrition knowledge and food-preparation skills for high-quality functioning and living. Home economics contents in Hong Kong are mainly intended for girls and not for boys. Due to numerous factors, such as the negative attitudes of teachers, parents, peers, and patriarchal community to home economics education, boys decide not to attend home economics classes. A similar situation is in Saudi Arabia, where home economics education is only intended for girls and not for boys (Alharbi \& Renwick, 2017). Such stereotypes greatly reduce home economics' educational and informative value (Dewhurst \& Pendergast, 2008).

Slovene studies (Matos, 2016; Murko, 2017; Štirn, 2016) show that gender inequality is not discernible in home economics education in Slovene schools. Urek (2018) notes that home economics education and literacy teaching is important and necessary for both genders. In a qualitative study, parents state that it would be sensible for home economics to be taught by more male teachers as female teachers are still predominant. A man can be a role model who demonstrates to pupils that an equal work division, regardless of gender, is important in families. Matos (2016) notes that parents emphasise that knowledge and skills related to basic household tasks must be presented to pupils from the point of view that both men and women carry out household tasks. Despite that, various authors (Collins et al., 2009; Jabs et al., 2007) realise that the division of household tasks within the family remain gender-determined, since women spend more time on housework than men. However, changes in the labour market and the employment of women lead to a necessary harmonisation of family and professional life.

Even the title of the subject is seen as problematic. In Slovenia, the term 'gospodinjstvo' (housekeeping) is used for home economics, the foreign name of the discipline. Historical documents indicate that such a denomination was questioned several decades ago; however, professionals support the idea of keeping the name as it is. In fact, IFHE endeavours to change the 'corporate image' of the discipline, but without changing the name (IFHE, 2008). Pendergast et al. (2013) point out that different terms for home economics cause further 
fragmenting of the discipline, while Taar and Vant (2017) emphasise that the name influences a person's perception of the subject. An in-depth study on the name and terms of the home economics subject has not yet been carried out in Slovenia. Lah (2015) notes that the name in Slovene does not reflect the actual span of the discipline and refers mainly to housekeeping. The Dictionary of the Slovenian Standard Language (SSKJ) (2008) defines 'gospodinjstvo' as performing or managing domestic or house tasks. Lah (2015) considers that with such an explanation of the word, the name of the domain which deals with more than managing domestic tasks is outdated and unsuitable. Other Slovene research shows divided opinions of different stakeholders on changing the name. Parents are divided over or undecided about the change in the name of the home economics subject (Matos, 2016), while future home economics teachers would rename it (Štirn, 2017); the study, however, did not research what the new name would be. No research on the opinion of Slovene home economics teachers as experts in their domain was found regarding the subject name.

\section{Home economics education in Slovenia and orientations for the future}

In Slovene elementary school education, pupils are supposed to acquire knowledge about healthy lifestyles and sustainable forms of organising social and economic life, to develop responsibility for their health and abilities for functioning in society, life-long learning and continuous personal growth, and to develop capacities to preserve the natural environment (Kalin et al., 2011). The Slovene nine-year compulsory school curriculum includes the home economics subject, which is compulsory for $5^{\text {th }}$ graders (children 10 years of age) and $6^{\text {th }}$ graders (children 11 years of age) and represents the basis of home economics education. Within this subject, students acquire knowledge and skills pertaining to the natural and social sciences. The subject includes four teaching modules: 1) Economics, 2) Textile and Clothing, 3) Living and the Environment, and 4) Nutrition. In the $5^{\text {th }}$ grade, the subject is taught for 35 hours. Students learn about the topics of the Economics and Textile and Clothing modules. In the $6^{\text {th }}$ grade, 52.5 hours are dedicated to home economics education, in which students learn about Living and the Environment and Nutrition. Home economics education stimulates students to reflect on contemporary problems at the individual, family, or societal levels. Students acquire the knowledge and skills for sustainable natural and social resources necessary to meet basic living needs. The main goal of the Economics module is for pupils to learn to adopt and evaluate decisions on personal and family economics, their needs, desires, values, and resources available. They are trained to be thrifty when using material goods, time, and energy. Pupils get to know the concept of family and 
understand that its members have different roles, understand the meaning of their name and surname, and learn how to prevent accidents at home. They develop a feeling of responsibility for meeting the needs and identifying the physical, emotional, intellectual and, social needs of children, adolescents, adults and aged people, and develop the feeling for helping people in distress and people with special needs. They learn about the forms of money and various payment methods, and they design financial plans for annual personal expenses.

In the Textile and Clothing module, pupils develop a sense for practical and aesthetically pleasing clothing. Pupils acquire basic knowledge of textile raw materials and textiles and use the acquired knowledge to choose, care for, and maintain their clothes. Together with aesthetic aspects and the suitability of clothes for various occasions, the economic and ecological aspects of clothes are underscored. The Textile and Clothing module has consumer education content about purchase planning and selecting and purchasing textile products. Pupils learn about advertisements, consumer protection, and various suppliers.

The Living and the Environment module includes contents on correct waste disposal, efficient energy consumption, and rational waste disposal, all strongly connected to environmentally-aware consumers. Contents cover the production of and information on products and services. Pupils learn about the impact of consumption on the environment and reflect on how they can contribute to improving it, thus developing a responsible attitude towards it. Consumer responsibilities are also covered.

In the Nutrition module, pupils become acquainted with, understand, use, and evaluate the importance of proper, safe, and protective diets. They develop the awareness of the impact of good and bad eating habits on their health; they are simultaneously accustomed to healthy and cultural eating habits and the correct and economical use of foods. They learn to plan daily meals by taking account of nutritional and energy values in a particular meal. Utensils and appliances for food processing and preparation are also covered. Pupils understand healthy eating recommendations and interpret their eating habits. They are taught to understand the information they read on food labels, the importance of correct food storage, and to respect hygiene standards when working with foods (Elementary school programme, Home Economics, 2011).

Characteristics of contemporary life require changes in home economics education. Society is changing, as are the social values on which it is based (Benn, 2009). Rosefsky Saavedra and Opfer (2012) emphasise how society is aware that knowledge and skills needed by pupils in today's world differ from those needed in the past. Problems that urgently require changing and updating home economics education and curricula of home economics subject are 
also addressed by some studies in Slovenia (Banič \& Koch, 2015; Erjavšek \& Lovšin Kozina, 2015; Erjavšek \& Kostanjevec, 2018; Erjavšek et al., 2018; Erjavšek et al., 2019; Erjavšek et al., 2021; Kostanjevec et al., 2018; Lah, 2015; Lovšin Kozina, 2015; Matos, 2016). The process of education and instruction involves various stakeholders. Kostanjevec et al. (2017) draw attention to the opinions of Slovene teachers, parents, and pupils regarding the content areas that they think should be included in the home economics curriculum to meet the needs of present-day Slovene society. The subject curriculum must include the knowledge and skills about sustainable development, consumption, textiles, financial literacy, healthy lifestyle, and healthy nutrition. To some extent, these contents are included in the currently applicable subject curriculum. According to the needs perceived, participants in the study think that home economics education should also include first aid, the living environment, technical tasks in a household, and that pupils should be enabled to develop social skills.

Erjavšek et al. (2018) note that the current subject curriculum includes some content areas identified by teachers as important for pupils to acquire by the end of primary education: economics, textiles, consumer education, sustainable consumption, nutrition and healthy lifestyle. Teachers state that, given the needs of society, home economics education should additionally cover health education, living environment, and the promotion of social skills development in pupils. In some studies (Matos, 2016; Urek, 2018), Slovene parents underline the importance of acquiring knowledge and skills in the area of sustainable development, with emphasis on sustainable behaviour and positive attitude towards the environment, consumption, textiles, financial literacy, nutrition, time management, quality functioning in the family and health literacy, and on proper handling accidents at home. To a certain extent, these contents are already included in the current curriculum of home economics subject. Parents find it important for pupils to acquire social skills, basic housekeeping skills, such as cleaning, tidying up, vacuum-cleaning the flat, and performing technical tasks in the household. This content is currently not included in the home economics curriculum.

Matos (2016) notes that the acquired home economics knowledge and skills, according to parents' opinions, should enable pupils to have high-quality, autonomous, responsible and independent lives and to maintain the home they will establish in future. At the same time, parents expect that home economics contents will focus on pupils' career orientations in terms of presenting professions in the domains where home economics discipline is active. Erjavšek et al. (2019) draw attention to the content areas which, in the opinions of pupils, should be acquired in home economics education before the completion of primary education. These are knowledge and skills in the areas of nutrition, 
economics, textiles, health, healthy lifestyle, environment, consumer education, home, use of domestic appliances, as well as social skills and communication. Some contents are well presented in the current home economics curriculum, while others should be added to meet the perceived needs.

The home economics subject in the Slovene educational system is placed in the fifth and sixth grades of elementary school, which means that the pupils are aged 10 and 11 years. Certain nutrition contents are upgraded in two elective subjects: Ways of Eating and Modern Food Preparation, which pupils can select in the seventh, eighth, or ninth grades (Elementary school programme, Ways of eating, 2009; Elementary school programme, Home Economics, 2011). Criticism about placing the home economics subject in the fifth and sixth grades can be observed. Teachers believe that home economics should be carried out during the seventh, eighth, and ninth grades (Erjavšek et al., 2018; Lah, 2015). Their views match the views of pupils and parents (Erjavšek et al., 2019; Matos, 2016; Urek, 2018). As home economics subject teaching ends in the sixth grade and its contents are treated mostly as modules, there is no vertical upgrading of the subject until the completion of elementary school. Pupils can upgrade their knowledge of certain nutrition content if they choose the elective subjects Ways of Eating or Modern Food Preparation. However, such upgrading (elective subject) is only obtained by some pupils and only in reference to nutrition contents. Both elective subjects cannot substitute for a dedicated home economics subject in the last three years of primary school.

The quality of teaching home economics is influenced by several factors, a major one of which is the adequate competences and qualifications of teachers who teach home economics (Dewhurst \& Pendergast, 2008; Håkansson, 2015). Legislation in Slovenia stipulates that a person can teach the home economics subject in the fifth grade with a completed study programme for a class teacher or a study programme for home economics. A person with a completed study programme of home economic can teach in the sixth grade. In the fifth and sixth grades, home economics teachers can also be those who fulfil the conditions to be biology or chemistry teachers in the elementary school education programme and have completed the relevant study programme of further training in home economics (Rules on education of teachers, 2015). Based on available elementary school data, Banič and Koch (2015) identified 170 class teachers who taught home economics to fifth-grade pupils in Slovenia in 2015. Lah (2015) notes many cases in which class teachers teach home economics in the sixth grade.

In Slovenia, future home economics teachers are educated at the Faculty of Education of the University in Ljubljana. Students who decide to study home economics acquire general subject-specific competences to teach the 
subject. General competences are obtained by acquiring knowledge and skills in basic educational sciences, while subject-specific competences refer to home economics content modules (Information Booklet, 2020-21a). During the first cycle of the elementary school study programme, graduates who are permitted to teach home economics obtain general but not the subject-specific competences that are essential to conducting home economics education (Information Booklet, 2020-21b).

Kostanjevec et al. (2018) note that Slovene teachers with inadequate formal education assess their competence to teach home economics contents lower than teachers with adequate formal education. In Slovenia, home economics is taught only by teachers who have been educated for the teaching profession, but it is not mandatory for them to have completed home economics studies. Teachers who have completed their studies of home economics obtain subject-specific competences and competences related to the general education professions. However, class teachers who often teach home economics acquire no specialised knowledge to teach home economics contents during their studies, since the study programmes include no relevant specialised contents, which can influence their competence to teach the subject. Banič and Koch (2015) state that class teachers who teach home economics are properly trained to plan lessons, but there is a disadvantage in that their studies provided them with no proper subject-specific competences to teach specialised contents. Teachers think that in the case of a lack of subject-specific competences their acquisition and knowledge of specialised contents in home economics is predominantly influenced by their general state of knowledge and interest in a particular area. Lindblom et al. (2013) assess that an adequate formal education of teachers who teach home economics is a prerequisite to teach the contents of home economics at an appropriate level. Teachers with adequate formal education are supposed to know and act according to the principle of uniform philosophy of the discipline and according to its overall principles, and they should have a positive attitude to the subject or the home economics discipline in general. They are key actors and promoters of home economics (Wahlen et al., 2009).

\section{Conclusions}

This article presents an overview of the areas of home economics, home economics education, and literacy-building throughout the world and in Slovenia. The role of home economics education in solving social problems is justified and in the challenges and problems of home economics in educational and social activities. 
When providing home economics education, the basic guidelines of the home economics discipline, defined in the 2008 IFHE Position Statement, should be taken into account. Due to the cultural and social determination in the field, the education process must be adapted to the time and space in which it takes place. Therefore, in updating home economics education, the needs of the current society must be respected. The following text gives some guidelines for the actualisation of home economics education in Slovenia. They aim to stimulate Slovene science and profession in the area of home economics to carry out discussions and future research towards reshaping the existing home economics education.

The existing curriculum of the home economics subject in Slovene elementary school should undergo content updating. It should cover healthy lifestyles, nutrition, health, textiles, consumption, economics, family, environment and sustainable development. To some extent, these contents are included in the currently applicable subject curriculum. In view of the perceived needs of various stakeholders included in the Slovene educational process (teachers, pupils and parents), the home economics curriculum should additionally include contents about home, and pupils should be prompted to develop their skills related to basic housekeeping tasks, such as cleaning, tidying up and vacuum-cleaning their home. Contents about the use of household appliances and health education with stress on first aid should be added, and pupils should be encouraged to develop social and communication skills. The existent and suggested contents encompass what is needed for the high-quality everyday functioning of a person. These are also reflected at family and society levels. Thus, the main goal of home economics education is fulfilled.

The contents of the subject should be treated theoretically and practically and, in this way, enable pupils to develop skills needed for quality and autonomous functioning and life. Theoretical knowledge should be transferred to concrete life situations, and pupils should be given opportunities to develop appropriate attitudes to home economics contents. Suitable material and staff conditions should be provided for the practical performance of these classes at schools. No research on problems and limitations influencing how home economics is taught in Slovenia could be found. This area should be researched and the discussion on concrete suggestions and solutions initiated.

In Slovenia's obligatory elementary school education, the home economics subject should also be placed in the third education period (from the seventh to the ninth grades). Currently, the subject is taught only in the fifth and sixth grades, and the contents are given in modules. Consequently, there is no vertical upgrading of home economics knowledge and skills in home 
economics education until the conclusion of elementary school. In the third education period, if one of the two elective subjects referring to the nutrition area (Ways of Eating and Modern Food Preparation) is selected by pupils, they can upgrade certain nutrition contents. This option can not, and must not, replace the need to place the independent subject of home economics in the last education period. The curriculum designers must respect the level of cognitive development of pupils and adapt the difficulty of contents to the particular education period.

Professional and scientific discussion in the area of home economics should be initiated on the denomination of home economics subject since the Slovene name does not reflect the actual span of the discipline, as it refers mostly to housekeeping. As in-depth research on the denomination or renaming of the subject in Slovenia has not been done yet, it would be sensible to implement it.

The legislation referring to who can teach home economics should be modified. It should only be taught by those who completed the study programme of home economics or those who completed an appropriate training programme in the subject. According to this definition, class teachers who are allowed, in line with the current legislation, to teach home economics to fifth graders, but often in practice also sixth graders, are not appropriately competent to teach the subject. During their studies, these teachers acquire no subject-specific competences in the subject.

As part of permanent education both, future home economics teachers and teachers who already teach this subject should be, during their studies and at study meetings for home economics teachers which are organised by the National Education Institute of the Republic of Slovenia, encouraged to develop their awareness on the meaning of home economics education for an individual, family and society. Home economics teachers should be key promoters of this discipline and should have a positive attitude towards it. The promotion of home economics at school and social as well as everyday life should be ensured. Promotion-oriented activities must be based on professional and scientific premises.

With their contents and inclusion in the education programme, the home economics discipline takes account of social changes that impact the lives of individuals and society. Proper adaptation to these changes and a better quality of life require, among others, high-quality home economics education and literacy teaching. 


\section{References}

Alharbi, M., \& Renwick, K. (2017). Saudi Arabian home economics curriculum: Searching for deep learning. International Journal of Home Economics, 10(2), 109-120.

Allwood, J. M., Laursen, S. E., De Rodríguez, C. M., \& Bocken, N. M. (2006). Well dressed. The present and future sustainability of clothing and textiles in the United Kingdom. University of Cambridge Institute for Manufacturing. https://www.ifm.eng.cam.ac.uk/uploads/Resources/Other_ Reports/UK_textiles.pdf Banič, M., \& Koch, V. (2015). Izkušnje učiteljev razrednega pouka s poučevanjem gospodinjstva [Experiences of primary school teachers in Home Economics teaching]. In M. Orel (Ed.), Sodobni pristopi poučevanja prihajajočih generacij (pp. 752-767). EDUvision.

Becirovic, S., \& Akbarov, A. (2015). Impact of social changes on teacher's role and responsibilities in the educational system. The Journal of Linguistic and Intercultural Education, 8, 21-34. Benn, J. (2004). Consumer education between 'consumership' and citizenship: Experiences from studies of young people. International Journal of Consumer Studies, 28(2), 108-116.

Benn, J. (2008). Some Danish remarks. International Journal of Home Economics, 1(1), 8-9. Benn, J. (2009). Practical wisdom, understanding of coherence and competencies for everyday life. International Journal of Home Economics, 2(1), 2-14.

Brown, M. M. (1980). What is home economics? Minnesota Research and Development Center for Vocational Education.

Caraher, M., \& McCloat, A. (2016). Home economics as a food education intervention: Lessons from the Irish secondary education context. Education and Health, 34(4), 104-109.

Casaló, L. V., \& Escario, J. (2016). Intergenerational association of environmental concern: Evidence of parents' and children's concern. Journal of Environmental Psychology, 48, 65-74. Collins, C., Collins, E., \& Mc Intosh, J. (2008). Home economics futures - possible scenarios and where they take us. Visionary insights into the future - 2028. In D. Pendregast (Ed.), Home economics: Reflecting the past; creating the future (pp. 115-131).

Collins, S. B., Neysmith, S., Porter, E., \& Reitsma-Street, M. (2009). Women's provisioning work: counting the cost for women living on low income. Community, Work \& Family, 12(1), 21-37. Davis, M. L. (2008). On identifying our profession. A response to the IFHE position statement. Home economics in the 21st century. International Journal of Home Economics, 1(1), 10-17. Dewhurst Y., \& Pendergast D. (2008). Home economics in the 21st century: A cross-cultural comparative Study. International Journal of Home Economics, 1(1), 63-83.

Dixon, R. (2017). Teachers' hopes for the future of home economics education in New Zealand. International Journal of Home Economics, 10(1), 12-20.

Erjavšek, M., \& Kostanjevec, S. (2018). Formal nutrition education and the inclusion of parents in promoting nutritional literacy of children. In M. Orel \& S. Jurjevčič (Eds.), Sodobni pristopi poučevanja prihajajočih generacij (pp. 742-751). EDUvision.

Erjavšek, M., \& Lovšin Kozina, F. (2015). Stališča učiteljev z ustrezno in neustrezno formalno 
izobrazbo za poučevanje gospodinjstva do predmeta gospodinjstvo [The attitudes of teachers with adequate and inadequate formal education to teaching home economics on the home economics subject]. In M. Orel (Eds.), Sodobni pristopi poučevanje prihajajočih generacij (pp. 743-751). EDUvision.

Erjavšek, M., Lovšin Kozina, F., \& Kostanjevec, S. (2021). In-service home economics teachers' attitudes to the integration of sustainable topics in the home economics subject. Center for Educational Policy Studies Journal, 11(1), 27-47.

Erjavšek, M., Zupančič, T., \& Kostanjevec, S. (2018). Teachers' views on the importance of home economics education in elementary school. In M. Orel \& S. Jurjevčič (Eds.), Sodobni pristopi poučevanja prihajajočih generacij (pp. 772-778). EDUvision.

Erjavšek, M., Žabkar, N., \& Kostanjevec, S. (2019). Elementary school pupils' attitude to home economics literacy. In M. Orel \& S. Jurjevčič (Eds.), Sodobni pristopi poučevanja prihajajočih generacij (pp. 1249-1258). EDUvision.

Gale Smith, M. (2013). Issues and directions for home economics/family studies/human ecology education: An epilogue. In M. de Zwart \& M. Gale Smith (Eds.), Proceedings of the Canadian Symposium XII Issues and Directions for Home Economics/Family Studies/Human Ecology Education (pp. 22-24). British Columbia.

Gale Smith, M. (2015). What does "Bring Back Home Ec" mean for us? Challenging the discourses of obesity and cooking. In M. de Zwart \& M. Gale Smith (Eds.), Proceedings of the Canadian Symposium XIII Issues and Directions for Home Economics/Family Studies/Human Ecology Education (pp. 129-150). Canada.

Goldsmith, E. B., \& Piscopo, S. (2014). Advances in consumer education: European initiatives. International Journal of Consumer Studies, 38(1), 52-61.

Gregorič, M., \& Fajdiga Turk, V. (2018). Prehranjevanje [Nutrition]. In M. Vinko, T. Kofol Bric, A. Korošec, S. Tomšič, \& M. Vrdelja (Eds.), Kako skrbimo za zdravje? Z zdravjem povezan vedenjski slog prebivalcev Slovenije 2016 (pp. 8-13). Inštitut za varovanje zdravja Republike Slovenije.

Hakansson, A. (2015). Indoctrination or education? Intention of unqualified teachers to transfer consumption norms in home economics teaching. International Journal of Consumer Studies, 39(6), $682-691$.

Harari, Y. N. (2020). 21 nasvetov za 21. stoletje [21 Lessons for the $21^{\text {st }}$ century]. Mladinska knjiga. Hira, T. K. (2013). Home economics literacy: Investing in our future. Journal of ARAHE, 2o(3), $113-118$.

Hira, T. K. (2015). World home economics day 2015 and 2016: Home economics literacy. https://he.ifhe. org/index.php?eID=tx_nawsecuredlinu=oing=oint=1537183713inhash=87fb2698b2c3c36ebf8f7bb97 37c44387370o1beinfile=fileadmin/user_upload/redaktion/IFHE_In_Focus/WHED/Article_HIRA_ WHED_2015_Literacy.pdf

Hodelin, G. B. (2008). Recasting home economics for the 21st century. A response to the IFHE position statement home economics in the 21st century. International Journal of Home Economics, $1(1), 18-21$. 
Höijer, K., Hjälmeskog, K., \& Fjellström, C. (2011). Food with a purpose? - Home economics teachers' construction of food and home. International Journal of Consumer Studies, 35(5), 514-519. IFHE (International Federation for Home Economics). (2008). IFHE position statement, home economics in the $21^{\text {st }}$ century. http://www.ifhe.org/index.php? $\mathrm{eID}=\mathrm{tx}$ nawsecuredlinu=oinfile=fileadmin/user_upload/redaktion/Publications/IFHE_Position_ Statement_2008.pdfint $=1276950317$ inhash $=0878$ b56fbdgea1b52ab4858efac2927c IFHE (International Federation for Home Economics). (2015). Press release: World home economics day 21 March 2015. Home economics literacy: Skills for families and consumers. IFHE.

IFHE (International Federation for Home Economics). (2016). IFHE world congress 2016 resolution. https://www.ifhe.org/fileadmin/user_upload/IFHE/IFHE_Resolutions/IFHE_Resolution_World_ Congress_2016.pdf Information Booklet. (2020-21a). Predstavitveni zbornik. Univerzitetni študijski program prve stopnje. Dvopredmetni učitelj [First Level University Study Programme. Two Subject Study Programmes] https://www.pef.uni-lj.si/fileadmin/Datoteke/Studijski_programi/Predstavitveni_zborniki/ Zborniki_20-21/Dvopredmetni_u\%C4\%8Ditelj_4.pdf Information Booklet. (2020-21b). Predstavitveni zbornik. Univerzitetni študijski program prve stopnje. Razredni pouk [First Level University Study Programme. First cycle of elementary school]. https:// www.pef.uni-lj.si/fileadmin/Datoteke/Studijski_programi/Predstavitveni_zborniki/Zborniki_2O-21/ Razredni_pouk_3.pdf Jabs, J., Devine, C. M., Bisogni, C. A., Farrell, T. J., Jastran, M., \& Wethington, E. (2007). Trying to find the quickest way: Employed mothers' constructions of time for food. Journal of Nutrition Education and Behavior, 39(1), 18-25.

Joy, A., Sherry Jr, J. F., Venkatesh, A., Wang, J., \& Chan, R. (2012). Fast fashion, sustainability, and the ethical appeal of luxury brands. Fashion Theory, 16(3), 273-295.

Kalin, J., Krek, J., Medveš, Z., Valenčič Zuljan, M., \& Vogrinc, J. (2011). Osnovna šola [Elementary school]. In Krek, J., \& Metljak, M. (Eds.), Bela knjiga o vzgoji in izobraževanju v Republiki Sloveniji (pp. 107-179). Zavod RS za šolstvo.

Kaplowitz, M. D., \& Levine, R. (2005). How environmental knowledge measures up at a big ten university. Environmental Education Research, 2(11), 143-16o.

Kieren, D., Vaines, E., \& Badir, D. (1984). The home economist as a helping professional. Frye Publishing.

Korhenen, K., \& Lappalainen, A. (2004). Examining the environmental awareness of children and adolescents in the Ranomafana region, Madagascar. Environmental Education Research, 2(10), $197-216$.

Kostanjevec, S., Lovšin Kozina, F., \& Erjavšek, M. (2017). Izzivi gospodinjskega opismenjevanja $\mathrm{v}$ osnovnošolskem izobraževanju [Challenges of teaching home economics literacy in primary education]. In M. Sardoč, I. Ž. Žagar, \& A. Mlekuž (Eds.), Raziskovanje v vzgoji in izobraževanju danes: zbornik povzetkov: 2nd nacionalna znanstvena konferenca (pp. 72-73). Pedagoški inštitut. Kostanjevec, S., Lovšin Kozina, F., \& Erjavšek, M. (2018). The relationship between teachers' 
education and their self-perceived competence for teaching home economics. Problems of education in the 21st century, 76(2), 175-187.

Lah, M. (2015). Odnos osnovnošolskih učiteljev do poučevanja predmeta gospodinjstvo [The attitude of primary school teachers towards teaching the home economics subject]. [Master's thesis, Univerza $\mathrm{v}$ Ljubljani, Pedagoška fakulteta].

Lai-Yeung, W. L. T. (2011). Nutrition education for adolescents: Principals' views. Asia Pacific Journal of Clinical Nutrition, 20(1), 87-94.

Lang, T., \& Caraher, M. (2001). Is there a culinary skills transition? Data and debate from the UK about changes in cooking culture. Journal of the HEIA, 8(2), 2-14.

Lichtenstein, A. H., \& Ludwig, D. S. (2010). Bring back home economics education. JAMA, 303(18), 1857-1858.

Lind, E., Pappel, K., \& Paas, K. (2009). Handicaft and home economics as designers of citizens who are able to cope in society. Citizenship, Social and Economics Education, 8(1), 54-62.

Lindblom, C., Erixon Arreman, I., \& Hörnell, A. (2013). Practical conditions for home and consumer studies in Swedish compulsory education: A survey study. International Journal of Consumer Studies, $37(5), 556-563$.

Lobstein, T., \& Jackson-Leach, R. (2016). Planning for the worst: Estimates of obesity and comorbidities in school-age children in 2025. Pediatric Obesity, 11, 321-325.

Lovšin Kozina, F. (2015). The primary school pupils' knowledge and attitudes on selected textile topics. Tekstilec, 58(4), 274-280.

Lusardi, A., \& Mitchell, O. (2014). The Economic importance of financial literacy: Theory and evidence. Journal of Economic Literature, 52(1), 5-44.

Ma, A., \& Pendergast, D. (2011). The past, the present and the preferred future for home economics education in Hong Kong. International Journal of Consumer Studies, 35(5), 589-594.

Magee, M., Yoo, T. M., Mok, C. F. J., \& Washi, S. (2010). Collective empowerment of the home economics profession - Equipping the profession with advocacy, futures creation and leadership.

International Journal of Home Economics, 3(1), 38-52.

Maknun, J., Syaom Barliana, M., Cahyani, D., \& Mardiana, R. (2016). The level of environmental literacy toward vocational high school students in West Java Province. Innovation of Vocational Technology Education, 2, 66-70.

Matos, B. (2016). Odnos staršev do gospodinjskega opismenjevanja otrok. [Parents' attitudes towards teaching children home economics literacy]. (Diploma thesis). Univerza v Ljubljani, Pedagoška fakulteta.

McGregor, S. L. T. (2016). Framing consumer education conceptual innovations as consumer activism. International Journal of Consumer Studies, 40(1), 35-47.

Mifsud, M. C. (2012). A meta-analysis of global youth environmental knowledge, attitude and behavior Studies. US-China Education Review B, 2(3), 259-277.

Mølstad, C. E. (2015). State-based curriculum-making: approaches to local curriculum work in Norway and Finland. Journal of Curriculum Studies, 47(4), 441-461. 
Mominova, R. N., \& Ibragimova, D. (2021). A healthy lifestyle and its importance. American Journal of Applied Sciences, 3(3), 1-6.

Morgan, L. R., \& Birtwistle, G. (2009). An investigation of young fashion consumers' disposal habits. International Journal of Consumer Studies, 33(2), 190-198.

Murko, A. (2017). Didaktični pristopi pri poučevanju prehranskih vsebin, vključenih v predmet gospodinjstvo [Didactic approaches in teaching nutrition content integrated in home economics subject]. [Master’s thesis, Univerza v Ljubljani, Pedagoška fakulteta].

Nanayakkara, J., Burton, M., Margerison, C., \& Worsley, A. (2018). Importance of home economics compared to other secondary school subjects: Australian parents' and young adults' views.

International Journal of Home Economics, 11(1), 72-79.

Neubauer, A. B., Schmidt, A., Kramer, A. C., \& Schmiedek, F. (2021). A little autonomy support goes a long way: Daily autonomy-supportive parenting, child well-being, parental need fulfillment, and change in child, family, and parent adjustment across the adaptation to the COVID-19 pandemic. Child Development, 92(5), 1679-1697.

Nutbeam, D. (1998). Health promotion glossary. Health Promotion International, 13(4), 349-64. OECD. (2009). Financial literacy and consumer protection: Overlooked aspects of the crisis. http:// www.oecd.org/finance/financial-markets/43138294.pdf

OECD. (2013). PISA 2012. Assessment and analytical framework: Mathematics, reading, science, problem solving and financial literacy. OECD Publishing. http://dx.doi.org/10.1787/9789264190511-en OECD. (2014). PISA 2012 results: Students and money: Financial literacy skills for the 21st century. http://www.oecd.org/pisa/keyfindings/pisa-2012-results-volume-vi.pdf Olafsdottir, S., Juniusdottir, R., \& Olafsadotti, A. S. (2017). Health promotion and home economics belong together-progress towards extended curricula in teacher education. International Journal of Home Economics, 10(2), 180-190.

Pace, E. M., Aiello, P., \& Sibilio, M. (2015). Applying the theory of simplexity in home economics education for the acquisition of transversal competencies to face complexity. International Journal of Learning, Teaching and Educational Research, 11(2), 71-87.

Pendergast, D. (2001). Virginal mothers, groovy chicks and Bbokey blokes: Re-thinking home economics (and) teaching bodies. Australian Academic Press.

Pendergast, D. (2008). Introducing the IFHE position statement. International Journal of Home Economics, 1(1), 3-7.

Pendergast, D. (2012). The intention of home economics education: A powerful enabler for futureproofing the profession. In D. Pendergast, S. L. T. McGregor, \& K. Turkki (Eds.), Creating home economics future: The next 100 years (pp. 12-24). Australian Academic Press.

Pendergast, D. (2013). An appetite for home economics literacy: Convergence, megatrends and big ideas. Journal of ARAHE, 20(2), 57-65.

Pendergast, D. (2015). HELM - home economics literacy model - A vision for the field. Victorian Journal of Home Economics, 54(1), 2-6.

Pendergast, D., \& Dewhurst, Y. (2012). Home economics and food literacy: An international 
investigation. International Journal of Home Economics, 5(2), 245-263.

Pendergast, D., Garvis, S., \& Kanasa, H. (2011). Insight from the public on home economics and formal food literacy. Family and Consumer Sciences Research Journal, 39(4), 415-430.

Pendergast, D., Garvis, S., \& Kanasa, H. (2013). The value of home economics to address the obesity challenge: An evaluation of comments in an online forum. International Journal of Home Economics, $6(2), 272-285$.

PISA. (2021). Financial literacy analytical and assessment framework. https://www.oecd.org/pisa/ sitedocument/PISA-2021-Financial-Literacy-Framework.pdf

Pravilnik o izobrazbi učiteljev in drugih strokovnih delavcev v izobraževalnem programu osnovne šole. (2015). [Rules on education of teachers and other expert workers in the elementary school education programme]. Uradni list RS, št. 109/11, 10/12, 92/12, 49/13 in 75/15. http://pisrs.si/Pis.web/ pregledPredpisa?id=PRAV10943

Pridāne, A. (2017). The study on competence-based curriculum implementation in the subject home economics and technologies. http://lufb.llu.lv/conference/REEP/2017/Latvia-Univ-AgricultREEP-2017_proceedings-376-384.pdf

Program osnovna šola. Gospodinjstvo. Učni načrt. (2011). [Elementary school programme, Home Economics, Curriculum]. Ministrstvo za šolstvo in šport: Zavod RS za šolstvo. http://www.mizs.gov.si/ fileadmin/mizs.gov.si/pageuploads/podrocje/os/prenovljeni_UN/UN_gospodinjstvo.pdf Program osnovna šola. Načini prehranjevanja in Sodobna priprava hrane. Učni načrt. (2009). [Ways of eating and Modern food preparation]. Ministrstvo za šolstvo in šport: Zavod RS za šolstvo. http:// www.mizs.gov.si/si/delovna_podrocja/direktorat_za_predsolsko_vzgojo_in_osnovno_solstvo/ osnovno_solstvo/program/abecedni_seznam_izbirnih_predmetov_v_osnovni_soli/\#c1786o Renold, U. (2008). The role of education in equipping individuals and families to be resilient and active participants in the global community. International Journal of Home Economics, 1(2), 69-74. RIC. (2021). Nacionalno preverjanje znanja [National assessment of knowledge in 9-year period]. https://www.ric.si/preverjanje_znanja/predmeti/

Roldan, A. T. (2017). Home economics research: Instilling hope, re-directing source of happiness in individuals and families of contemporary society. International Journal of Home Economics, 1o(1), 151-161.

Rosefsky Saavedra, A., \& Darleen Opfer, V. (2012). Teaching and learning 21st century skills. https:// asiasociety.org/sites/default/files/T/teaching-and-learning-21st-century-skills-rand.pdf Saribas, D., Teksoz, G., \& Ertepinar, H. (2014). The relationship between environmental literacy and self-efficacy beliefs toward environmental education. Procedia - Social and Behavioral Sciences, 116, 3664-3668.

Scarborough, W. J., Collins, C., Ruppanner, L., \& Landivar, L. C. (2021). Head start and families' recovery from economic recession: Policy recommendations for COVID-19. Family Relations, 7o(1), $26-42$.

Sheridan Rains, L., Johnson, S., Barnett, P., Steare, T., Needle, J. J., Carr, S., Taylor, B. L., Bentivegna, F., Edbrooke-Childs, J., Scott, H. R., Rees, J., Shah, P., Lomani, J., Chipp, B., Barber, N., Dedat, Z., 
Oram, S., Morant, N., \& Simpson, A. (2021). Early impacts of the COVID-19 pandemic on mental health care and on people with mental health conditions: Framework synthesis of international experiences and responses. Social Psychiatry and Psychiatric Epidemiology, 56, 13-24.

Slater, J. (2013). Is cooking dead? The state of home economics food and nutrition education in a Canadian province. International Journal of Consumer Studies, 37(6), 617-624.

Slater, J., \& Hinds, A. (2014). University student perceptions of home economics: Food and nutrition education. International Journal of Home Economics, 7(2), 68-80.

Sproles, K. E., \& Sproles, B. B. (2000). Careers serving families and consumers. Prentice Hall. SSKJ - Slovar slovenskega knjižnega jezika. (2008). [Dictionary of Slovenian literary language].

SAZU.

Stage, S., \& Vincenti, E. (1997). Rethinking home economics, women and the history of the profession. Cornell University Press.

Street, P. (2006). Home economics education in New Zealand: A position statement. http:// nzcurriculum.tki.org.nz/Curriculum-resources/NZC-resource-bank/Health-and-physicaleducation/Supporting-materials

Štirn, P. (2016). Odnos študentov do vsebin gospodinjstva [Students' attitude towards home economics contents]. (Diploma thesis). Univerza v Ljubljani, Pedagoška fakulteta.

Taar, J., \& Vant, T. (2017b). The role of the school subjects' name on its content and image. http://llufb. llu.lv/conference/REEP/2017/Latvia-Univ-Agricult-REEP-2017_proceedings-392-399.pdf Tamm, J., \& Palojoki, P. (2012). New curriculum, new directions? Using socio-cultural perspective to develop home economics education in Estonia. http://lufb.llu.lv/conference/REEP/2012/REEP-2012proceedings-E-ISSN-2255-808X.pdf Tuncer, G., Tekkaya, C., Sungur, S., Cakiroglu, J., Ertepinar, H., \& Kaplowitz, M. (2009). Assessing pre-service teachers' environmental literacy in Turkey as a means to develop teacher education programs. International Journal of Educational Development, 29(4), 426-436.

Tuomisto, M., HaapaniemI, J., \& Fooladi, E. (2017). Close neighbours, different interests? Comparing three Nordic home economics curricula. International Journal of Home Economics, 10(2), 121-131. Turkki, K. (2005). Pre-professionals' perceptions of home economics in Finland. International Journal of Consumer Studies, 29(3), 273-282.

Urek, V. (2018). Stališča staršev o pomenu usvajanja znanj in veščin pri gospodinjskem izobraževanju [Parents' views on the importance of acquiring knowledge and skills in home economics education]. (Master’s thesis). Univerza v Ljubljani, Pedagoška fakulteta.

Vidgen, H. A., \& Gallegos, D. (2014). Defining food literacy and its components. Appetite, 76, 50-59. Volāne, E. (2014). The acquisition of primary school pupils' life activity skills in the aspect of teaching content of home economics and technologies. http://llufb.llu.lv/conference/REEP/2014/Latvia-UnivAgricult-REEP-2014proceedings-162-171.pdf Wahlen, S., Posti-Ahokas, H., \& Collins, E. (2009). Linking the loop: Voicing dimensions of home economics. International Journal of Home Economics, 2(2), 32-47.

Werner, E. N., Guadagni, A. J., \& Pivarnik, J. M. (2020). Assessment of nutrition knowledge in 
division I college athletes. Journal of American College Health, 2000, 1-8. https://doi-org.nukweb. nuk.uni-lj.si/10.1080/07448481.2020.1740234

WHO. (2014). European food and nutrition action plan 2015-2020. http://www.euro.who.int/_data/ assets/pdf_file/ooo8/253727/64wd14e_FoodNutAP_140426.pdf

WHO. (2021). Obesity and overweight. https://www.who.int/news-room/fact-sheets/detail/obesityand-overweight

Woodruff, S. J., \& Kirby, A. R. (2013). The associations among family meal frequency, food preparation frequency, self-efficacy for cooking, and food preparation techniques in children and adolescents. Journal of Nutrition Education and Behavior, 45(4), 296-303.

\section{Biographical note}

MARTINA ERJAVšEK is a teaching assistant for home economics education at the Department of Biology, Chemistry and Home Economics at the Faculty of Education, University of Ljubljana, Slovenia. She is a PhD student at the Faculty of Education, University of Ljubljana. Her main areas of research are: home economics and nutrition literacy, home economics education and society needs, sustainable and responsible living in connection with home economics education. 